\title{
Financial constraints on economic development: Theory and policy for developing countries
}

\author{
Jennifer Hermann
}

ABSTRACT

This article contains a theoretical and policy analysis of the financial constraints on economic development in developing countries. Following a Keynesian interpretation, it concludes that financial policies are needed to relieve these constraints, given the natural tendency of financial systems to operate in ways that are dysfunctional to economic development. It then proposes three lines of policy that take account of the special characteristics of developing countries: resource allocation policies targeted at segments of strategic importance for economic and financial development; policies to control financial and external fragility; and compensatory policies of a more interventionist cast, in particular directed credit programmes for both public- and private-sector lending to complement resource allocation policies, and countercyclical regulatory barriers so that fragility can be better controlled.

KEYWORDS

JEL CLASSIFICATION

AUTHOR
Economic development, development finance, financial policy, financial services, credit, Keynesian economics, developing countries

G18, O16, O50

Jennifer Hermann is a Professor at the Institute of Economics of the Federal University of Rio de Janeiro (IE/UfRJ), Brazil. jenniferh@terra.com.br 


\section{I}

\section{Introduction}

The importance of financial dynamism to economic development is generally acknowledged and has been empirically confirmed in innumerable studies on the subject. History shows, however, that there is no one ideal model for a financial system capable of supporting economic development and that very few countries have managed to combine financial and economic development. The only instances that can be cited are Germany, the United Kingdom and the United States, the latter two with a financial system based on capital markets, the former with one based on private credit (Zysman, 1983). Other countries whose industrialization accelerated in the post-war period, including the developing countries studied in this article, backed the process with some combination of public and external credit, and the varying degrees of success they achieved revealed the mismatch between the dynamics of their financial systems and the financing needs of economic development.

Although generalizing is difficult, it is possible to identify features common to countries at similar levels of development. In industrialized countries, it is innovation that is hardest to finance, both in the research and development (R\&D) phase and in the new process implementation phase (Hall, 2002; Matouk, 2010), given the particular riskiness of these investments. In developing countries, the challenges raised by underdevelopment itself and by competition from more advanced economies create further difficulties. A number of sectors have a particularly acute need for resources, but underdevelopment is also a feature of financial systems, which are usually limited and undiversified (Gerschenkron, 1962; Furtado, 1967). In these cases, economic performance may be directly constrained by the shortcomings of a country's financial system.

The present article is a contribution to this debate and contains a theoretical and policy analysis intended to assist in the task of understanding and identifying financial constraints on economic development in developing countries. At the theoretical level, it offers a Keynesian interpretation drawing on the work of two offshoots of this tradition, the new-Keynesian school, represented here by the contributions of J. Stiglitz (Stiglitz and Weiss, 1981; Stiglitz, 1994), and post-Keynesian thinking as derived from the writings of J.M. Keynes (1943, 1937a and 1937b) and H. Minsky (1982 and 1986). Setting out from this interpretation, the article proposes a basic list of financial policies designed to make the financial system more functional to economic development, bearing in mind the special characteristics of the countries aspiring to this.

Section II starts the discussion with a summary of the theoretical debate on the role of the financial system in economic development. The sections that follow apply the Keynesian approach to the analysis of developing countries, concentrating on three aspects: their specific economic development financing needs (section III), the conditions under which the financial system can contribute to this process (section IV) and the profile of the financial policy required to expand it (section V). Section VI offers conclusions.

\section{II}

\section{The financial system and economic development}

J. Schumpeter (1934) and J.M. Keynes (1943, 1937a and 1937b) laid the foundations for the theoretical debate about the macroeconomic role of the financial system. Schumpeter highlighted the importance of credit to economic development and Keynes argued that the money market was the main driver of economic dynamics in both the short and the long run.
The debate was stoked in the 1950s and afterwards by the publication of a well-known article by Gurley and Shaw (1955), followed by other important contributions that include Gurley and Shaw (1960), Shaw (1973), McKinnon (1973), Stiglitz (1994) and Minsky (1982 and 1986), among others. The first of the articles cited gave rise to the Gurley-Shaw model and the next two 
to the Shaw-McKinnon model, both of which derive from the neoclassical theoretical tradition and are briefly summarized in the following subsection. The last two, which are described in more detail further on (since they provide the basis for the policies proposed in this paper), provided the main theoretical underpinnings for the Keynesian approach in its new-Keynesian and post-Keynesian variants, respectively.

\section{A brief summary of the neoclassical view}

The Gurley-Shaw model postulates that a diversified financial system providing a variety of ways to allocate savings is favourable to economic growth. A kind of Say's Law is proposed for the financial market: a supply of profitable assets, with varied characteristics, tends to attract a portion of aggregate saving, thus creating its own demand. Thus, the demand for money and equilibrium interest rates are lowered and the supply of funds to finance investments is increased. This approach, however, says nothing about what conditions and policies favour financial development, an issue that is not dealt with until the Shaw-McKinnon model.

The Shaw-McKinnon model relies on three core hypotheses (Fry, 1995; Hermann, 2003): (i) saving is required to finance economic growth; (ii) aggregate saving is a positive function of the real interest rate, and (iii) freely operating financial markets ensure that the real interest rate, aggregate saving and, by extension, economic growth settle at their "optimum" levels.

The first two hypotheses are simply applications of well-known neoclassical monetary theory. The third synthesizes the efficient market hypothesis (Malkiel, 1994), according to which, in the absence of exogenous barriers to agents' free choices, interest rates correctly reflect the microeconomic and macroeconomic fundamentals of the assets concerned.

According to this approach, any market segment becomes viable if it is free to price assets in accordance with their fundamentals. A situation where financing for economic development is constrained is interpreted as a symptom of malfunctioning not in the financial system, but in the wider economy of which it is part.

What is recommended for the creation of a "complete" financial market, then, are: (i) liberalization policies so that regulatory obstacles do not prevent prices from adjusting to asset risks and returns; (ii) supervision of the sector (to safeguard individual investors), and (iii) macroeconomic policies focused on monetary stability to keep risk levels low. According to this approach, such policies stimulate asset demand (by reducing risk) and supply (by reducing costs) and foster market diversification (by doing away with regulatory barriers), thus promoting financial development.

\section{The Keynesian approach}

The Keynesian approach to the financial system is based on a position that is critical of the efficient market hypothesis. In new-Keynesian theory, this hypothesis is replaced by that of market failures, structural conditions that, even in free markets, prevent prices from adjusting to economic fundamentals. In the financial market, the main failure identified is information asymmetry between potential borrowers and lenders. ${ }^{1}$ Because of this asymmetry, banks cannot properly distinguish the differing risk levels of potential borrowers and thus set efficient interest rates for each project. Given this limitation, they set homogeneous rates for projects that differ in riskiness. This results in a first source of inefficiency: equilibrium interest rates in the market for assets do not properly reflect their microeconomic fundamentals, because the lender does not perfectly know them. Since it is not possible to identify each risk, banks follow two conventional evaluation criteria: (i) the greater the rate of return, the higher the risk (Tobin, 1958), and (ii) the interest rate accepted by borrowers is indicative of the returns they expect and their appetite for risk. Accordingly, even if lenders anticipated high levels of risk, incorporating them fully into interest rates would not be a solution, owing to the adverse selection effect (attracting borrowers with a greater risk appetite and putting off more conservative ones). Thus, potential lenders tend to protect themselves by rationing credit and causing the market to become incomplete in segments where it is particularly hard to evaluate or compensate for risk. ${ }^{2}$ Rationing and incompleteness arise most frequently:

(i) In the capital market, as it is highly risky for nonprofessional investors.

(ii) In long-term financing and the financing of innovations generally, as risks are hard to predict.

(iii) In lending to small and medium-sized enterprises (SMEs).

\footnotetext{
1 Other market failures may be noted, such as transaction costs, information costs, positive and negative externalities, incomplete markets and imperfect competition (Stiglitz, 1994; IDB, 2005, chap. 11). All except the last are intrinsic to financial markets.

${ }^{2}$ A market is deemed incomplete when one or more segments that are theoretically possible do not exist in practice because of a lack of interest on the demand or supply side.
} 
(iv) In lending to people on low incomes, who are considered risky because of their lower levels of income and collateral, so that in many countries they are affected by financial exclusion.

The indisputable importance of these segments for economic development highlights another inefficiency in the financial system: its tendency to operate in a way that is not functional to this process.

The post-Keynesian approach is even more radical in its criticism of the efficient market hypothesis, its argument being that the main obstacle to market efficiency is the uncertainty surrounding all economic decision-making, and particularly financial operations (Carvalho, 2010; Hermann, 2011a). As Kregel (1980) observed, the problem is not confined to information costs and access, but includes the very existence, at the critical juncture, of the forward-looking indicators needed to estimate asset risks and returns. Uncertainty, unlike risk, cannot be priced, i.e. cannot be factored into market interest rates. This makes it reasonable that there should normally be some preference for liquidity, as a way of protecting against unforeseeable risks.

In Keynes's view, the preference for liquidity is the main source of macroeconomic inefficiency in resource allocation, both in asset markets, where it creates a short-termist tendency that makes it harder (and more expensive) to finance investment, and in the market for goods, where it is the main cause of recessions. This exacerbates the difficulties involved in financing economic development, as already discussed. The post-Keynesian view is that these difficulties reflect, on a larger scale, the difficulties of financing aggregate investment. According to Keynes, such financing is carried out in two stages. The first, which he called the finance stage, consists in demand for credit from firms to initiate new investments, and can be met with shortterm loans. For investments to be completed, however, firms must be able to issue longer-dated securities (including shares) whose maturities are compatible with that of the asset to be financed. Keynes called this the funding stage.

As Kregel (1986) observed, the finance stage is not obligatory, since investment can be financed directly by issuing shares or long-term debt. This situation is less likely than the one depicted by Keynes, however. In both stages, what makes the investment viable is a context of low (or falling) preference for liquidity (which reduces equilibrium interest rates in the asset market), but willingness to forego liquidity obviously needs to be greater in the funding phase. This has implications for financing costs: the interest rates demanded for longterm securities by the savers and financial institutions that might acquire them are generally higher than those for short-term securities. In other words, the yield curve (the interest-rate term structure) is typically rising (Cargill, 1983; Hermann, 2011b). This situation makes the second phase more fraught than the finance phase, implying that activities requiring long-term funding will be penalized more heavily.

In the finance phase, the crucial actors are commercial banks; as they take in sight deposits (very short-term liabilities), they also concentrate their assets in short-term operations. Once this demand has been met, investment generates new income and thence more saving. Longterm funding is not guaranteed even if savings are identical in value to new investments (Keynes, 1937a), since where there is a strong preference for liquidity, savings will be allocated predominantly to short-term assets (including cash). In this phase, non-bank financial institutions need to be willing and able to attract new savings for medium- and long-term assets.

With the Keynesian approach, in summary, the vital actors in the investment financing process are not savers (firms and families keeping resources in the financial system) but financial institutions: commercial banks in the finance phase and other financial institutions (including universal banks) in the funding phase (Carvalho, 1997). This interpretation justifies the central role attributed in the post-Keynesian approach to the financial system as a key factor in economic development.

Besides the preference for liquidity, uncertainty justifies what Keynes (1943, chap. 12) called conventional behaviour: going along with the majority at times when risks are hardest to evaluate. Because of this, the market tends to amplify asset appreciation or depreciation trends, creating speculative bubbles in the first case and asset deflation crises in the second. Minsky (1982 and 1986) adds to this analysis the financial fragility hypothesis, pointing out that: (i) phases of economic growth are always accompanied by higher debt; (ii) the level of debt tends to rise with the degree of development of the financial system; (iii) the expectations driving this borrowing are surrounded by uncertainty; (iv) the ability to make repayments may be jeopardized when these expectations are not met, creating the risk of liquidity crises in the financial system, and (v) fulfilment of these expectations does not in itself guarantee safety for the market either, as it tends to prolong phases of bullishness, sometimes unduly, thus creating speculative bubbles that likewise trigger financial crises when they burst (Kregel, 1997). 
Financial fragility in market economies thus has structural causes: the uncertainty inherent in financial relationships and the development of the financial system itself. The degree of fragility in the economy in each period will depend on the conditions of the lending contracts signed. On this subject, Minsky offers a taxonomy of borrowers, classifying them as: (i) hedgers, whose expected incomes exceed their debt repayments; (ii) speculative borrowers, whose expected income (in the early phase of the contract) only covers interest costs, making it necessary to refinance the principal, and (iii) Ponzi schemes, used by speculative borrowers who are even greater risk-takers and expect to refinance the principal and the interest in that initial phase. Speculative borrowers (including those engaged in Ponzi schemes) operate with a greater degree of fragility since, besides the risk of their earnings expectations not being met, they depend on new loans to cover the maturity mismatch between their assets (longer) and their liabilities (shorter).

Thus, financial fragility in the economy is increased by two factors: the size of agents' debts and the proportion of speculative borrowers. The former reflects the rate of economic growth and the degree of financial development in the country, with progress in this tending to expand agents' access to external financing sources. As for the latter, a large proportion of speculative borrowing is not an anomaly but a common feature reflecting the chronic difficulty of securing long-term financing in market economies, which induces firms to borrow short in order to finance assets with long maturities. Financial system fragility is thus intrinsic to financial development.

In short, from a post-Keynesian perspective, the financial system tends to operate in a way that is doubly dysfunctional to economic development: market incompleteness in the segments with the greatest uncertainty compounds the tendency towards financial fragility.

Keynesian-inspired approaches argue for a number of forms of State action in the financial system. Besides the supervision of the sector suggested in the neoclassical approach, recommended policies include prudential regulation (restrictions on the free allocation of resources) ranging from incentives to specific allocations to priority sectors and, given the difficulties of development financing, more interventionist types of action as well, involving public-sector and directed private-sector lending policies, with the former perhaps extending to the creation of public-sector development banks.

\section{III}

\section{The financing of economic development}

\section{Characteristics of the development process}

Economic development is a complex phenomenon requiring prolonged gross domestic product (GDP) growth in conjunction with structural transformations in the economy. This process is brought about by a series of investments in new production capacity, in two ways: the capital stock is expanded and new types of physical and human capital are brought into use. Thus, development always involves some degree of innovation, which comes about through the introduction of new products, sectors of activity, production processes and consumption patterns (Schumpeter, 1934).

A general movement towards increased investment of the kind that characterizes each phase of economic development needs something to supplement selffinancing. From this basic condition arises the importance of financial development for economic development, as the various schools of theory dealing with the issue recognize. The complexity of the development process, however, has major implications when it comes to understanding and determining financing needs (Studart, 2005; Carvalho, 2010; Hermann, 2011a). The greatest difficulties include:

(i) The large volume of capital required: this restricts many firms' access to what prove to be scarce or costly outside resources.

(ii) Innovations: new sectors, products and production processes do not have a track record of profitability, and this exposes innovative firms to credit rationing, as well as limiting their ability to self-finance.

(iii) Externalities: some of the investments needed to advance the development process are used to expand productive and urban infrastructure, often with the characteristics of a public good (with a social return greater than the expected microeconomic return), which limits private-sector interest. 
(iv) Consumption: for investment and innovation to expand sustainably, domestic consumption needs to grow too. As with investment, this increased consumption can hardly be financed from personal resources alone, even if these tend to grow because of increased employment and, possibly, some improvement in the income distribution profile. Thus, favourable borrowing conditions for families are an important complement to the financing structure of economic development.

(v) Possible effects on the trade balance: some of the forward and backward linkage effects created by the new investment can result in certain sectors quickly coming up against the limit of their capacity, creating bottlenecks on the supply side, while other effects may stimulate demand in sectors that have the capacity to expand supply but are not very competitive externally. In both cases, imports (of capital, intermediate or consumption goods) will be strongly stimulated, resulting in balance-of-payments disequilibria and possibly inflation (Tavares, 1979; Furtado, 1967). In this case, the development process will only be sustainable under favourable external financing conditions.

(vi) Financial market incompleteness: when the financing of a particular firm is considered, it is implicitly or explicitly assumed that there is a diversified financial infrastructure enabling the firm to assess market opportunities and opt for the combination of its own and outside capital that best suits it. In other words, markets are assumed to be complete. According to the theoretical approach adopted in this study, as has been shown, this condition is not guaranteed even for individual firms, let alone the whole economy.

Given these conditions, it is clear that, by contrast with what conventional approaches recommend, the financing of economic development requires far more than free markets and business expertise if "optimum" capital structures are to be created. In the absence of a diversified financial system geared in some degree towards dealing with the specific needs of this process, even the most promising projects can be rendered unviable by financing difficulties.

\section{Special features of developing countries}

The effort to understand the heterogeneity of economic development in different countries gave rise to a taxonomy ranking them into three major categories in the international economy: (i) developed countries (also known as industrialized countries because the industrial sector dominated this process until the late twentieth century), which head the ranking;

(ii) underdeveloped countries, a term that gradually fell into disuse so that in the 1980s they became known instead as developing or less developed countries, with a subdivision by income levels (medium and low);

(iii) emerging economies, a term used for developing countries that implemented trade and financial liberalization policies in the 1980 s or 1990 s, so that international connections became substantially more important in their development profile.

The first indicator normally offered as a marker for developing countries is their level of GDP and per capita income, which have historically been lower than in industrialized countries with similar populations and land areas. Strictly speaking, what distinguishes developing countries is that they have remained in this position for decades or even centuries. Despite this, developing countries are not exactly characterized by difficulty in achieving economic growth, even if this is a recurrent problem in many of them. The greater difficulty is to generate development, i.e. to associate growth with structural shifts that enhance economic and social indicators and the country's position in the international market:

"Underdeveloped economies can experience prolonged phases of growth in their overall and per capita output without any diminution of the external dependency and structural heterogeneity that are their essential characteristics" (Furtado, 1967).

What distinguishes developing countries more than their relatively low incomes is the difficulty they have in implementing and, most particularly, generating innovations in an international market already dominated by technologically more advanced countries. Thus, many authors consider technological underdevelopment the main distinguishing feature of developing countries. Although hard to measure, this can be clearly perceived in some of its effects: (i) the low productivity of capital and labour by developed-country standards; (ii) chronic difficulty in competing in domestic and external markets even under favourable exchange-rate conditions; (iii) import and export patterns concentrated, respectively, in industrial and primary goods; (iv) frequent trade deficits, and (v) high external indebtedness, among other things.

Other features of developing countries are a high degree of financial system incompleteness and external constraints, although these conditions are also present 
to some degree in industrialized countries. ${ }^{3}$ The special characteristics of developing countries in these respects are the greater intensity with which problems manifest themselves and the extent of the constraints they place on development.

On the Keynesian view, as has been shown, the financial system tends to operate in a way that is largely dysfunctional to economic development in any country. It is widely recognized, for example, that capital markets are difficult to develop anywhere because of the greater risks and costs they involve relative to the banking sector (Herring and Chatusripitak, 2000). Financing difficulties and even financial exclusion in higher-risk segments are also found in industrialized countries (Dymski, 2005 and 2006). In developing countries, however, lower incomes and economic growth difficulties constrain the expansion of the financial system in lower-risk segments too, so that even short-term credit is scarce and dear. Besides, higher-risk groups are a larger share of the population in less-developed countries, which aggravates the resource scarcity affecting them.

Under these conditions, yield curves in developing countries acquire a profile that is quite unfavourable to

\footnotetext{
${ }^{3}$ Other conditions not directly related to development financing are often identified as causes or manifestations of the relative backwardness of developing countries. These conditions include: (i) the large share of GDP represented by goods with low value added, reflecting lesser access to more elaborate technologies; (ii) poor production and urban infrastructure and inadequate education and health services, which feed back into technological underdevelopment; (iii) low wages, reflecting a poorly trained workforce and a low investment rate; (iv) a greater tendency to inflation in both growth and recession stages, driven by a number of factors that include the high propensity to consume typical of low-income economies; (v) low productivity; (vi) distributional conflicts, and (vii) frequent currency devaluations to cope with the external constraints.
}

potential borrowers (Hermann, 2011b): starting from a high base that reflects the high cost of short-term credit, they are short (because the market is incomplete in long-term segments) and steep (because of the chronic reluctance of the financial system to engage in longer-term lending, which is also manifested in the high cost of the loans that are made despite this rationing) (see figure 1).

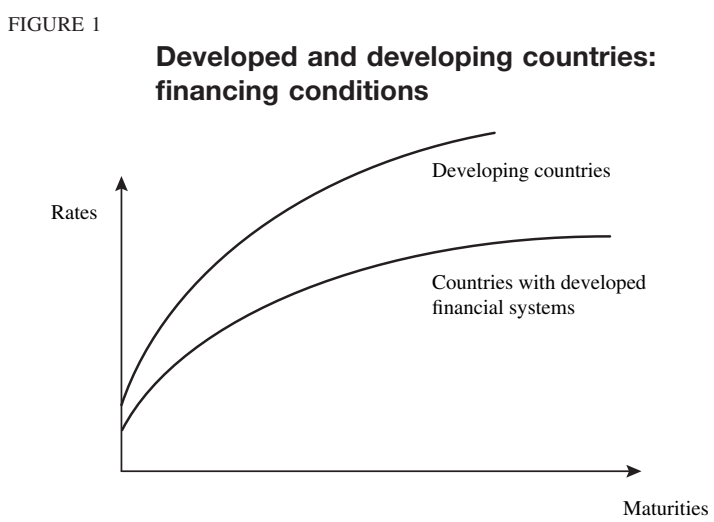

Source: prepared by the author.

As for the external constraint, given the growing importance of international trade and financial relationships, any country's development process is shaped (and ultimately constrained) by the performance of its balance of payments. In developing countries, though, this constraint tends to take the form of a chronic problem because it derives from a structural situation, namely greater dependence on external financing, either to make up for the incompleteness of the financial system or to cover balance-of-payments deficits associated with technological underdevelopment.

\section{IV}

\section{The functionality of the financial system to economic development}

A basic condition for a financial system to operate in a manner functional to economic development in any country is the availability of a diversified set of financial institutions and instruments capable of meeting both the varied demands associated with this process and the profit objectives of the financial institutions themselves (Carvalho, 2010). This condition, however, cannot be equated with the concepts of efficiency and financial development as these terms are usually employed. The former, which is common to neoclassical approaches, emphasizes the microeconomic functions of the financial system, the aim of which is to meet the profit objectives of financial institutions and enhance their clients' wealth. The efficient market hypothesis maintains that 
performing these functions efficiently is a necessary and sufficient condition for the financial system to also perform its macroeconomic function of providing finance for production activity.

The Keynesian approach does not deny the importance of these microeconomic functions, but it rejects the efficient market hypothesis and, with it, the equivalence between microeconomic and macroeconomic efficiency in the financial system. Besides the natural tendency of financial systems towards incompleteness when it comes to meeting economic development needs, there is the fact that the conditions determining the efficiency of the financial system are not all necessarily met at the same time. A financial system can perform the financing function with a structure that is both undiversified (with a heavy concentration of commercial banks, for example) and inefficient at assessing risk. This was the contradiction identified in developing countries by the theorists of financial liberalization (Shaw, 1973; McKinnon, 1973), who attributed the problem to the policy of financial repression, i.e. to strong State action through regulation and public credit programmes.

It is also possible for a financial system to meet the objective of increasing wealth without properly performing the financing function. This has been the case in many developing countries since the liberalization policies of the 1990s, which sought to expand and diversify financial systems but left many existing financing difficulties in place, including financial exclusion and external dependency (Hermann, 2004).

The functionality of the financial system cannot be equated with the idea of financial development either, when the term is understood, as it usually is, in a purely quantitative sense. On this definition, development is measured by aggregated indicators such as the number and types of financial institutions, the value added of their assets, the size of the sector and the scale of lending as a share of GDP, etc. ${ }^{4}$ Although important, these indicators are not enough to capture the broader concept of macroeconomic functionality. According to Keynes's and Minsky's approaches, a financial system functional to economic development needs to be able to fulfil two essential conditions in addition to the physical existence of a diversified financial structure: (i) the ability to meet the demand for financial resources in its various forms, encompassing both finance and funding needs, and (ii) the ability to control the level of financial fragility, given that some fragility is inevitable:

\footnotetext{
4 An example of this type of approach can be found in IDB (2005, chap. 1).
}

"Functionality is defined as follows: a financial system is functional to the process of economic development when it expands the use of existing resources in the process of economic development with the minimum possible increase in financial fragility and other imbalances, that may halt the process of growth for purely financial reasons" (Studart, 1995, p. 64).

The special conditions of developing countries suggest two extensions of Studart's concept. First, the expansion of existing resources needs to meet certain allocation criteria to reduce credit rationing and the financial exclusion affecting sectors essential to development. A financial system that is functional to economic development in developing countries needs to have a variety of financing mechanisms to support: (i) investment in innovations in all their phases; (ii) expansion and modernization of productive and urban infrastructure; (iii) small and medium-sized enterprises (SMEs); (iv) sectors with the characteristics of a public good; (v) home ownership, and (vi) durable goods consumption. The low-income population should be included in the last two cases.

Where the financing of innovations is concerned, given the high degree of uncertainty and credit rationing involved, the experience of more developed countries points to the capital market as the best channel, operating essentially through venture capital funds. Thus, meeting the requirement of functionality involves a more specific requirement for the structure of the financial system: capital market development.

The second needful extension of Studart's concept concerns financial fragility: to be functional to development in developing countries, a financial system needs to have mechanisms to monitor external financial fragility in the area of what the author calls "other imbalances". By analogy with Minsky's original concept, this fragility is determined by currency mismatches, which can result from the build-up of foreign currency borrowings by agents whose income is in local currency (i.e. everyone except exporters) or from maturity mismatches in exporters' external debts.

From the Keynesian theoretical perspective, therefore, the concept of functionality needs to encompass four aspects: (i) the volume of resources; (ii) allocation to sectors that are strategically important to development; (iii) domestic financial fragility, and (iv) external financial fragility. Although these dimensions may be dealt with separately for analytical purposes and usually require different instruments for good results, they are not independent of one another, as the absence 
of one may compromise the rest. For example, excessive credit expansion and misallocation of resources (with maturities shorter than the ideal or very high costs) increase financial fragility in the economy. Fragility can spread to the external sector if these financial system failings are compensated for by high external borrowing. Lastly, a high degree of financial fragility or external fragility in the economy tends to restrict the supply of funds, making it hard for the resource volume condition to be met.

The issues of allocation and external fragility are especially important in developing countries. Given the chronic difficulty of raising funds in the domestic market, external fragility becomes an almost inevitable tendency in phases of abundant international liquidity.
Except where there are barriers (economic or otherwise) to foreign capital, these phases result in a large expansion of external borrowing in developing countries. Thus, some of the financial fragility of these countries is manifested as external fragility.

This interpretation is not meant to suggest that the volume of resources is irrelevant but only to emphasize that, taken alone, it says little about the functionality of financial systems in developing countries. Resource volume growth is supposed to be an indicator of improving financing conditions in any country, but this hypothesis is only borne out if the expansion is properly directed, reducing the degree of credit rationing and financial exclusion without unduly increasing financial and external fragility.

\section{V}

\section{Policies to enhance the functionality of financial systems in developing countries}

A major practical implication of Keynesian financial theory is that, given the natural tendency of the financial system towards incompleteness and financial fragility, it is unlikely to qualify as functional to economic development in the absence of State action to achieve this (Carvalho, 2010; Hermann, 2011a) in the form of: (i) policies to encourage the development of the financial system with a view to making it less incomplete; (ii) policies to control domestic and external financial fragility, always recognizing that these tendencies cannot be wholly eliminated from the financial system, and (iii) compensatory policies to supplement the other two kinds. This section discusses possible lines of action in each of these areas, taking the four dimensions of financial functionality for developing countries referred to above.

\section{Policies on the amount and allocation of resources}

The policies needed to induce the financial system to expand its operations in segments essential to economic development have to be guided by the extent and characteristics of financial system incompleteness in each developing country. Despite these countries' specific characteristics, their financing difficulties have features in common: the scarcity and costliness of both short- and long-term private financing sources, summed up in high, short and steep yield curves.

The incentive policies needed to improve the situation would have to include measures to stimulate demand for financial assets, particularly long-term ones, including variable-income securities (shares), in the capital market. As regards compensatory policies, what are recommended are directed private-sector lending programmes and, most particularly, public credit policies targeted on sectors essential to development in each period, with pricing and maturities that are less onerous than the terms available in the market (in segments where this option exists).

As will now be argued, such policies, taken together, have the effect of lowering, extending and flattening yield curves in the different segments of the financial system. In addition, they indirectly serve to reduce the financial fragility involved in economic development, as better maturity and cost conditions reduce credit risk.

Demand for a given asset is shaped by estimates of its likely risks and returns relative to alternative assets; by the macroeconomic environment, there being an increased preference for liquidity in situations of great uncertainty and for longer-dated securities at times of greater optimism; and by the incentive structure that financial policy creates (Carvalho, 2010). Besides a macroeconomic environment of low uncertainty, what 
is needed to stimulate demand for long-term assets is an incentive structure that produces some comparative advantage for these assets over lower-risk ones. This structure can be created in two ways, which are not mutually exclusive: increased risk-adjusted rates of return for long-dated securities, and lower rates for short-dated securities. The profile of the yield curve in developing countries points to the latter as the most advisable course.

Reducing short-term interest rates favours longerdated operations (including the capital market) in two ways: (i) it will lower the yield curve, thus reducing the costs of all financial operations, including long-term ones, by also causing the curve to lengthen, and (ii) it will flatten the yield curve, reinforcing the previous effect, since lower returns on short-dated securities will tend to increase investors' preference for longer-dated assets, which will provide the only route to increased profitability for their portfolios in the new environment of low interest rates (figure 2).

FIGURE 2

Developing countries: the effects of lower short-term interest rates on the yield curve

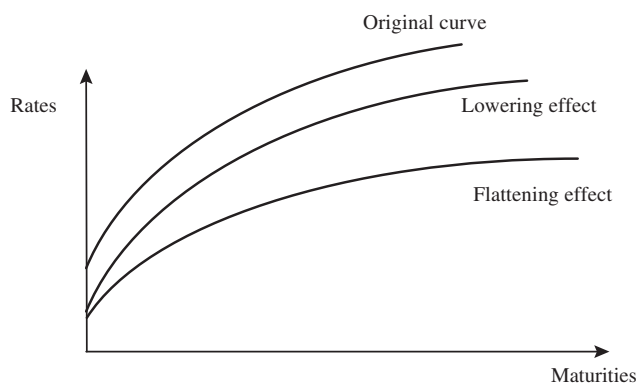

Source: prepared by the author.

A systematic policy of encouraging low shortterm interest rates also contributes to a macroeconomic environment that is more favourable to financial development. High interest rates tend to have a perverse effect on the demand for assets in general because of adverse selection, which increases credit risk for lenders (Stiglitz and Weiss, 1981) and potentially compromises returns. Uncertainty and the preference for liquidity increase in this context, penalizing longer-dated assets in particular.

Short-term rates that are appropriately low (i.e. that do not create the macroeconomic imbalances mentioned below) tend to reduce borrowing risks and, by stimulating economic growth, improve expectations of returns on assets, including longer-dated ones. The constraints on this policy are, naturally, the risks of inflation, overborrowing (and thence financial crises) and balance-of-payments disequilibria. Nonetheless, the perverse effects of a high interest-rate policy are such that, even given these risks, it should be used with diffidence and on a temporary basis and be supplemented by other instruments that act more directly on these macroeconomic disequilibria (discussion of which is beyond the scope of this article).

In summary, this paper rejects the idea, upheld by the Shaw-McKinnon model and widely propounded in this debate, that high interest rates might contribute to economic development, whether in developing or developed countries, by expanding the supply of loanable funds. According to the Keynesian approach, higher interest rates can, at least in theory, increase the profits of financial institutions, thereby stimulating lending. This possibility, however, is subject to two types of risk: a rapid rise in defaults by borrowers and the consequent risk of a financial crisis. In both cases, the profitability of financial institutions will be negatively affected and credit growth will be cut short. Thus, it is considered that a policy of low short-term interest rates would do more good than harm to the economic development process: in conjunction with the risk spreads of each form of financial operation (reduced, ideally, by macroeconomic policy), such interest rates would result in final rates that were reasonable for borrowers and compatible with the levels of returns that financial institutions consider reasonable and satisfactory.

Lastly, what a directed credit policy requires first and foremost is the creation of secure long-term funding sources to ensure that the private- or public-sector banks discharging this function do not end up creating the very financial fragility (and fiscal fragility too in the case of public-sector banks) that they ought to be mitigating. Given the environment of constrained demand for long-term assets in which these policies have to be implemented, the best source of long-term funding to underpin them are non-market resources, i.e. funds that are fiscal or parafiscal (compulsory saving) in origin.

Second, in practice these policies can only succeed in compensating for the lack of lending to sectors deemed strategically important to development if credit is actually provided when required. In this respect, public-sector credit tends to be more effective than directed credit. The latter, although it may help to make the market less incomplete, suffers from a limitation common to more indirect forms of State action in the financial system (supervision, regulation and incentives), in that it is a non-coercive policy which only acts through incentives. 
Directed credit programmes create rules for allocation from particular private-sector funding sources, or make public fiscal or parafiscal funds available at below-market costs so that these institutions can provide the loans in question. These measures are meant to induce privatesector institutions to provide credit, but do not force them to, so their effectiveness may be limited by the same lack of interest that caused the market to be incomplete in the first place. Thus, the only sure way to improve the situation is for the government to directly take on the risks the private sector rejects. This requires the creation of development banks, i.e. public-sector banks with specific functions in the economic development process.

\section{Policies on financial fragility}

\section{(a) Domestic financial fragility}

Financial fragility can be partially controlled by market hedging mechanisms such as highly liquid assets, organized secondary markets, market makers, futures markets and derivatives. For these operations to take place, however, it is necessary for the financial system to have a reasonably well-developed capital market, which is rarely the case in developing countries. This limitation reinforces the need referred to earlier for these countries to coordinate allocation policies with those designed to control financial fragility.

Even in countries that meet this condition to some degree, however, the fact that hedge operations, like the ones covered by them, are based on expectations means that these market instruments may prove inadequate or even counterproductive as a financial system defence measure. This is so, for example, in situations of particular asset price volatility, which encourage speculative operations aimed rather at profit than at protection, and those where herd behaviour takes over, since volatility makes it hard to arrive at reliable estimates (Kregel, 1997).

Under such conditions, what is required if these instruments are to be negotiated with reasonable security is not just physical infrastructure in the form of financial institutions and markets but also an institutional (regulatory) infrastructure operating on two fronts: (i) preventive control of risk-taking in the financial system, and (ii) compensation of the macroeconomic effects when preventive measures prove inadequate or ineffective.

Preventive regulation needs to focus on protection for the end saver and control of financial fragility. What is basically required for the former is a regulatory apparatus that establishes the responsibility of financial institutions for providing information on the risks of operations they undertake using resources raised from savers and, at least in part, for any resultant losses. Besides protecting savers, which is necessary in itself, such regulation contributes indirectly to the development of the country's financial system by making the market more attractive to savers in general.

As for financial fragility, although prudential regulation can only deal with specific operations, its final objective from the point of view of the functionality of the financial system must be to control systemic risk, i.e. the degree to which the economy is exposed to risk in the financial system. As well as the risks taken or caused by specific agents, the possible channels of contagion between them are also important. Controlling systemic risk requires restrictions on the build-up of speculative debts (including Ponzi schemes), as a way of managing risk-taking, and on the leverage of financial institutions, to limit contagion between them.

Agents' borrowing profiles and the channels of contagion in the financial system are not clearly perceptible in the economy, however, which means that despite the macroeconomic cost involved in restricting the potential growth of the whole market, action to forestall systemic risk needs to rely essentially on control of the overall risk exposure of the financial system. Historically, such control has involved subjecting financial institutions to regulatory barriers and costs associated with the expansion of their lending operations (Carvalho, 2005).

Regulatory barriers usually take the form of market segmentation preventing commercial banks from operating in the capital market, along the lines of the Glass-Steagall Act of 1935 in the United States. The main objective of such a ban is to prevent contagion between the two segments of the financial system. Although successful in the United States and several other countries up until the 1980s, this model fell into disuse from the 1990s with the spread of liberalization policies (likewise initiated in the United States), which promoted the gradual removal of regulatory barriers to the free choice of portfolios by financial institutions.

In this new financial system model, the only option left is to impose costs on the choices with the greatest potential to generate systemic risk, essentially those involving the greatest liquidity risk (Carvalho, 2009). These costs have taken a variety of forms (Carvalho, 2005): the requirement for minimum levels of liquidity and capital on the balance sheets of financial institutions (compulsory levies on deposits, loan provisions, Basel rule, etc.), similar regulation of the derivatives market (off-balance sheet operations) using liquidity and capital buffers, and tax measures, among others. 
In developing countries classified as emerging markets, where capital markets are reasonably well developed, prudential regulation needs to be extended to both the corporate debt and the share segments of these markets. Corporate debt is similar to bank credit, except for the greater liquidity of corporate securities, even though this is typically not very high either (Herring and Chatusripitak, 2000). Shares do not increase the level of debt in the economy, and indeed are an alternative to debt, but nor are they free from systemic risk. This essentially derives from: (i) the market risk typical of shares; (ii) this segment's greater exposure to herd behaviour, facilitated by the liquidity of shares relative to other types of assets, and (iii) the fact that many investors, and especially larger ones, are leveraged, i.e. work with borrowed resources, creating the risk of banking-sector contagion in the event that the share market performs poorly.

Controlling the systemic risk associated with the capital market thus requires instruments similar to those applied to banks: requiring intermediaries to disclose information accurately and making them liable for any losses that result from failures in this regard; requiring liquidity and capital buffers; and limiting financial institutions' leverage and holdings of securities on their balance sheets.

The effectiveness of the cost-based risk control model is limited, however, by factors that are largely beyond the control of the regulatory authorities, such as the phase of the business cycle and ongoing financial innovation. Where the business cycle is concerned, prudential regulation can be expected to be least effective in expansion phases when markets are most bullish, which is just when financial expansion most needs controlling. The financial system tends to play down the burden of regulatory costs in this situation, expecting them to be more easily offset by the greater earnings forecast. This limitation can be eased, although not wholly overcome, by a countercyclical structure for regulatory costs based, for example, on a sliding scale of costs that rises with the volume of resources or with the rate of expansion of each type of operation to be controlled.

Financial innovations place a twofold limitation on the effectiveness of controls designed to prevent financial fragility by imposing costs. First, they gradually make the current cost structure obsolete, as certain types of operation become less of a feature of the market. Second, they make it hard to recalibrate control instruments, since the new types of operation are still relatively unknown:
"Innovation (both financial and organizational) [...] is in itself a source of institutional unsuitability. [...] $[\mathrm{U}] \mathrm{nder}$ the effect of the development of financial systems, formal institutions [...] become ineffective and no longer sufficiently counter the endogenous dynamic of risk taking" (Sinapi, 2011, p. 18).

These limitations suggest the advisability of applying compensatory policies of more direct intervention in the financial system to supplement prudential regulation, such as: (i) regulatory barriers to risk-taking by financial institutions; (ii) emergency hedging instruments for times of particular uncertainty (emergency open market operations using public securities and currency, for example); (iii) lending of last resort by the central bank to financial institutions with temporary liquidity problems; (iv) programmes to restructure the banking sector when there are prolonged difficulties indicative of solvency problems, and (v) circuit breaker mechanisms in the capital market implemented by official regulators or by private-sector self-regulation bodies.

\section{(b) External financial fragility}

As has been pointed out, the external financial fragility of developing countries is structurally determined by the profile of their production structure and the particularly fragile position they thus occupy in the international financial market. These conditions are beyond the scope of financial policy action, which does however play an important role in controlling the systemic risk associated with possible contagion in the domestic financial system when a country's external fragility results in liquidity difficulties for financial institutions. This contagion can take place via three channels: the external liabilities of financial institutions themselves, those of the non-financial sector (including balance sheet and off-balance sheet operations in both cases), and the currency market.

The first of these produces contagion, in particular, from the financial system to the balance of payments, since in this case the liabilities of the financial system are one of the causes of the country's external fragility. Contagion through the second channel arises as a counterpart of the external fragility of the non-financial sector, whose demand for currency can unleash a large-scale movement to redeem domestic financial investments, increasing banks' very short-term liabilities (in reserves). Systemic crises arising through these two channels can be avoided if the flow of external liabilities is compatible with the volume of currency available in the country. Thus, the systemic risk associated with these channels can be contained by a strategy similar to the one identified earlier 
for controlling domestic financial fragility: regulatory limits on the accumulation of external liabilities by the financial system and the non-financial sector, conjoined with differentiated control measures that should focus on short-term transactions, as these keep demand for currency systematically high.

Contagion through the currency market takes place when adverse exchange-rate movements are able to inflict major losses on the financial system. Given that developing countries are more likely to suffer from external fragility, exchange-rate depreciation is particularly risky because it raises the cost of a country's external liabilities (including the financial system's) and aggravates the effects from the other two channels. Currency appreciation, however, is not necessarily beneficial for a developing country's financial system, as it will tend to worsen its international trade position, thereby exacerbating external fragility. Moreover, in developing countries with reasonably developed futures markets, a category that includes most emerging markets, both currency depreciation and appreciation can inflict large losses on the financial system in the event that it is heavily committed to currency derivatives, since it is enough for the direction or strength of the exchangerate movement to take a large part of the market by surprise.

In this context, there needs to be a permanent policy of controlling exchange-rate volatility in addition to the limits on external liabilities already referred to. The latter reduce the exposure of the financial system to exchange-rate risk, while controls on volatility, by making the exchange rate more predictable, tend to reduce the currency risk entailed in any kind of operation that creates external liabilities.

In the managed exchange-rate regimes that prevailed in developing countries until the late 1990s, currency volatility was avoided by the constant action of central banks committed to keeping the exchange rate at the level set. As second-generation models indicate (Obstfeld, 1994), the sustainability of these regimes depends on the confidence of the market, and financial institutions in particular, in the ability of the central bank to meet the exchange-rate target announced. If this condition is not met, the country becomes vulnerable to speculative attacks (such as a sudden increase in the preference for foreign currency over local-currency investments) strong enough to force the central bank to alter the exchangerate target or, in extreme cases, to abandon the managed exchange-rate regime altogether. As is well known, the severe shock to the credibility of these regimes from the trade and financial liberalization policies implemented in developing countries in the 1990s triggered a series of currency crises there and led to the old model being replaced with floating currency regimes.

Exchange-rate volatility is a fact of life in floating currency regimes since, by definition, the central bank does not adopt any formal commitment on the exchange rate. On the other hand, an unquestionable commitment by any government to macroeconomic stability, which implies some degree of monetary and financial-system stability, requires central banks operating hybrid regimes with flexible exchange rates to engage in the task of containing currency volatility. This gave rise to the dirty float regimes that became predominant in the late 1990s.

In this model, exchange-rate volatility can be controlled by central bank interventions in spot and futures markets involving the trading of currencies and currency derivatives. In spot operations, the bank acts directly on the current exchange rate, while in the futures market it influences exchange-rate expectations. In neither case, however, is the central bank wholly immune to difficulties deriving from the great mobility of capital, which limit its ability to control the exchange rate in managed currency regimes. Specifically, in situations of great uncertainty, herd behaviour in the financial system limits the central bank's ability to act in the face of strong pressure for currency appreciation or depreciation. Given that ultimately these situations cannot be avoided, it is advisable for central banks not only to act on the price of the currency, but also to introduce mechanisms to control the capital flows influencing this.

Selective countercyclical control of capital inflows is particularly important in developing countries, given their greater propensity to borrow abroad at times when foreign investors are particularly bullish. Regulatory or tax barriers to capital inflows at these times, with greater restrictions on short-term operations, help to forestall excessive expansion of external borrowing. In very bearish phases, likewise, selective controls can be applied to discipline the movement of capital outflows from the country. In both cases, the country's external fragility and the volatility of the currency market are mitigated.

Note should be taken, finally, of the risk that policies to control financial fragility may conflict with development financing needs, as they tend to restrict the total volume of operations in the financial system. This dilemma shows the extreme importance of coordinating such control with the allocation policies mentioned earlier in order to shape a financial system that is more functional to development. 


\section{VI}

\section{Conclusions}

To be functional to economic development, a financial system must be capable of meeting its financing needs at acceptable cost and with appropriate maturities. The absence of these conditions does not necessarily prevent the process from moving forward, but it does give it a "stop and go" character, as the financing structure will suffer from a high degree of financial fragility due to the preponderance of high-cost short-term debt, and perhaps external fragility too, in cases where the shortcomings of the domestic financial system are compensated for by external borrowing. Thus, a functional financial system is not just a desirable condition that facilitates economic development but a necessary one if this process is not to turn into a source of systemic risk and, in all probability, of banking and currency crises that impose major sacrifices on the economy.

From a Keynesian perspective, as has been shown, the normal operating conditions of the financial system tend to make it generally incomplete and dysfunctional, even in countries at an advanced stage of economic and financial development. Thus, it is unlikely that these conditions will be achieved without State policies designed for the purpose. In developing countries, the difficulties are compounded by the very conditions that mark them out as less developed, in particular a lack of structural diversification in the financial system and intermittent dependence on external financing. These conditions make developing countries more subject to periods of growth without development (Furtado, 1967) and to financial fragility, especially in its external dimension, creating a vicious circle that perpetuates their unfavourable position on the international stage.

Improving the situation requires a coordinated set of financial policies, resting on two pillars: (i) allocation policies, focusing on segments of strategic importance to economic and financial development, and (ii) policies to control financial fragility, both domestic and external. Considering, however, that even large and diversified financial systems still show signs of behaviour that is dysfunctional to economic development (such as a lack of interest in projects with the character of public goods, financial exclusion, etc.), incentive- and cost-based conventional policies aimed at deregulated markets will not be enough to induce an adequate degree of functionality in developing-country financial systems.
Accordingly, there is also a need for compensatory policies of more direct intervention wherever stimulation or restraint is called for. This group includes, in particular: (i) programmes of directed public- or private-sector credit in the field of allocation policies (with beneficial indirect effects for the control of financial fragility as well); (ii) non-market regulatory barriers in the field of financial fragility control policies, and (iii) countercyclical measures to restrict the free flow of capital in order to control external fragility.

Interventionist policies are not risk-free either. The difficulties encountered by agents generally in predicting the behaviour of relevant indicators also affect the government bodies responsible for implementing these policies. Even so, the financial history of the twentieth century and the early decades of this one suggests that the macroeconomic damage deriving from this forecasting risk could be less than that deriving from market risk. ${ }^{5}$

During the five decades the interventionist model lasted (from the mid-1930s to the 1980s), no systemic crisis struck the world economy, despite the indisputable progress of economic and financial development. In that period, the world experienced two mortgage crises (during the 1970s and 1980s) originating in rich countries with great influence on the international market, the United States and Japan, plus the Latin American external debt crisis of the 1980s. Although these were very painful for the countries affected, the regulatory barriers of the time meant that none turned into an international systemic crisis.

The events of recent years, however, have not been a good advertisement for the incentive-based conventional financial policy model that has predominated in the era of liberalization. In a little over 20 years of existence, this model has not been able to prevent two systemic crises of international reach, coming against a background of lower economic growth than in the earlier period: the crisis in developing Asia, which began in 1997 and spread to Latin America between 1999 and 2003, and

\footnotetext{
5 The exception is the political risk (of corruption, for example) associated with any kind of government action. This is not a specific problem of financial policy, however, or even of economic policy in general, but is of a political and legal nature and ought to be dealt with in that context.
} 
the crisis that began in 2008 (symptomatically enough in the "cradle of liberalization", the United States) and is still ongoing as of 2013. The latter crisis reinforces the hypothesis that the current model is ineffective, as it has been severest in rich countries with developed financial systems.

Without ignoring the differences in macroeconomic context that make linear comparison between the periods and countries concerned impossible, it is difficult not to associate these crises with the shift in the model for controlling systemic risk that resulted from financial liberalization. Recent events make it advisable, at the very least, for the subject of interventionist policies (which need not necessarily be in the same mould as the old ones) to be put back on the agenda of the continuing debate about possible ways of making the financial system more functional to economic development, not just in developing countries, but in industrialized ones too.

\section{Bibliography}

Cargill, T. (1983), Money, the Financial System and Monetary Policy, Englewood Cliffs, New Jersey, Prentice-Hall.

Carvalho, F.J. Cardim de (2010), "Reformas financeiras para apoiar o desenvotlvimento", Textos para Discussão CEPAL-IPEA, No. 14 (LC/BRS/R.231), Brasilia, Economic Commission for Latin America and the Caribbean (ECLAC)/Institute of Applied Economic Research (IPEA).

(2009), "Systemic crisis, systemic risk and the financial instability hypothesis", Macroeconomic Policies on Shaky Foundations, E. Hein, T. Niechoj and E. Stockhammer (eds.), Berlin, Metropolis-Verlag.

(2005), "Inovação financeira e regulação prudencial: da regulação de liquidez aos Acordos de Basiléia”, Regulação financeira e bancária, R. Sobreira (org.), São Paulo, Editora Atlas.

(1997), "Financial innovation and the post Keynesian approach to the "process of capital formation", Journal of Post Keynesian Economics, vol. 19, No. 3, M.E. Sharpe.

Dymski, G.A. (2006), "Discrimination in the credit and housing markets: findings and challenges", Handbook on the Economics of Discrimination, William Rodgers (ed.), Cheltenham, United Kingdom, Edward Elgar.

(2005), "A eficiência social e a regulação bancária: lições da experiência americana", Regulação financeira e bancária, R. Sobreira (org.), São Paulo, Editora Atlas.

Fry, M.J. (1995), Money, Interest and Banking in Economic Development, London, Johns Hopkins University Press.

Furtado, C. (1967), Teoria e política do desenvolvimento econômico, São Paulo, Companhia Editora Nacional.

Gerschenkron, A. (1962), Economic Backwardness in Historical Perspective: A Book of Essays, Cambridge, Massachusetts, Belknap Press of Harvard University Press.

Gurley, J. and E. Shaw (1960), Money in a Theory of Finance, Washington, D.C., Brookings Institution.

(1955), "Financial aspects of economic development", The American Economic Review, vol. 45, No. 4, Nashville, Tennessee, American Economic Association, September.

Hall, B.H. (2002), "The financing of research and development", Working Papers, No. E01-311, Berkeley, University of California, Berkeley, January.

Hermann, J. (2011a), "Política financeira e desenvolvimento econômico: um debate a partir de contribuições recentes de Fernando Cardim de Carvalho", Anais do IV Encontro Internacional da Associação Keynesiana Brasileira, Rio de Janeiro, Institute of Economics, Federal University of Rio de Janeiro, August.

(2011b), "O mercado de títulos privados e a inadequação da curva de rendimentos no Brasil: análise teórica e da experiência pós-estabilização (1995-2010)", Working Paper, No. 14, Brazilian Development Bank (BNDES)/National Association of Postgraduate Centers in Economics (ANPEC)
(2004), "O trade off do crescimento no Brasil nos anos 1990-2000: análise crítica e alternativas de política monetária", Revista Econômica, vol. 6, No. 2, Rio de Janeiro, December.

(2003), "O modelo de liberalização financeira dos anos 1990: 'restatement' ou auto-crítica?", Nova Economia, vol. 13, No. 2, Belo Horizonte, Federal University of Minas Gerais, July-December.

Herring, R.J. and N. Chatusripitak (2000), The Case of the Missing Market: The Bond Market and Why It Matters for Financial Development, Tokyo, Wharton Financial Institutions Center, May.

IDB (Inter-American Development Bank) (2005), Relatório 2005. Libertar o crédito: como aprofundar e estabilizar o financiamento bancário, Rio de Janeiro, Campus.

Keynes, J.M. (1943), General Theory of Employment, Interest, and Money, London, Macmillan.

(1937a), "Alternative theories of the rate of interest", The Economic Journal, Hoboken, New Jersey, Wiley, June.

(1937b), "The "ex-ante theory' of the rate of interest", The Economic Journal, Hoboken, New Jersey, Wiley, December.

Kregel, J. (1997), "Margins of safety and weight of the argument in generating financial fragility", Journal of Economic Issues, vol. 31, No. 2, Association for Evolutionary Economics, June. (1986), "A note on finance, liquidity, saving, and investment", Journal of Post Keynesian Economics, vol. 9, No. 1, Armonk, M.E. Sharpe.

(1980), "Markets and institutions as features of a capitalistic production system", Journal of Post Keynesian Economics, vol. 3 , No. 1, Armonk, M.E. Sharpe.

Malkiel, B.G. (1994), "Efficient market hypothesis", The New Palgrave Dictionary of Money and Finance, P. Newman, M. Milgate and J. Eatwell (eds.), London, Macmillan Press Limited.

Matouk, J. (2010), "Financing innovation: an historical approach", Journal of Innovation Economics, vol. 6, No. 2, De Boeck University.

McKinnon, R. (1973), Money and Capital in Economic Development, Washington, D.C., The Brookings Institution.

Minsky, P.H. (1986), Stabilizing an Unstable Economy, New Haven, Yale University Press.

(1982), "The financial fragility hypothesis: an interpretation of Keynes and an alternative to 'standard' theory", Can It Happen Again? Essays on Stability and Finance, H.P. Minsky, New York, M.E. Sharpe, Inc.

Obstfeld, M. (1994), "The logic of currency crises", NBER Working Paper, No. 4640, Cambridge, Massachusetts, National Bureau of Economic Research.

Schumpeter, J.A. (1934), The Theory of Economic Development, Cambridge, Massachusetts, Harvard University Press

Shaw, E.S. (1973), Financial Deepening in Economic Development, New York, Oxford University Press.

Sinapi, C. (2011), "Institutional prerequisites of financial within Minsky's financial instability hypothesis: a proposal in terms 
of "institutional fragility"”, Working Paper, No. 674, Dijon, Levy Economics Institute of Bard College, July.

Stiglitz, J. (1994), "The role of the state in financial markets", Proceedings of the World Bank Annual Conference on Development Economics 1993, Washington, D.C., World Bank.

Stiglitz, J. and A. Weiss (1981), "Credit rationing in markets with imperfect information", American Economic Review, vol. 71, No. 3, Nashville, Tennessee, American Economic Association, June.

Studart, R. (2005), "Financiamento do desenvolvimento", Economia Brasileira Contemporânea: 1945-2004, F. Giambiagi and others (orgs.), Rio de Janeiro, Campus.
(1995), Investment Finance in Economic Development, London, Routledge.

(1995-96), "The efficiency of financial system, liberalisation and economic development", Journal of Post Keynesian Economics, vol. 18, No. 2, M.E. Sharpe Inc.

Tavares, M. da C. (1979), Da substituição de importações ao capitalismo financeiro, Rio de Janeiro, Zahar Editores.

Tobin, J. (1958), "Liquidity preference as behavior toward risk", The Review of Economic Studies, vol. 25, No. 2, Oxford University Press, February.

Zysman, J. (1983), Governments, Markets and Growth, London, Cornell University Press. 